\title{
Tree-fall gaps and patterns of tree recruitment and growth in Andean old-growth forests in south-central Chile
}

\author{
Claros en el dosel y patrones de reclutamiento y crecimiento arbóreo en \\ bosques antiguos en la Cordillera de Los Andes del centro-sur de Chile
}

\author{
Mauro E González a*, Pablo J Donoso a , Paul Szejner a \\ *Autor de correspondencia: ${ }^{a}$ Universidad Austral de Chile, Facultad de Ciencias Forestales y Recursos Naturales, \\ Instituto de Conservación, Biodiversidad y Territorio, Valdivia, Chile, maurogonzalez@uach.cl
}

\begin{abstract}
SUMMARY
Canopy gaps have been recognized as an important process in the regeneration dynamics of Andean old-growth forests $\left(\mathrm{ca} .40^{\circ} \mathrm{S}\right)$. The objectives of the study were to determine main tree-fall gap attributes and to assess tree recruitment and growth patterns in tree-fall gaps of two mid-elevation Andean old-growth forests. We measured the canopy and expanded area of each gap, and for the gap-maker species we measured its diameter at breast height (dbh), felling direction and type of treefall. In each gap, tree seedlings, saplings and bamboo culms were counted in subplots. Increment cores of potential successors were obtained to examine growth patterns. There was a larger area in canopy gaps in NF than in STF (25.8 vs. $11.9 \%$ ). Expanded gaps were on average larger in NF than in STF (547 vs. $440 \mathrm{~m}^{2}$ ). Most gaps were originated by wind-snap and upturned root-plates of all the major tree species (Laureliopsis philippiana, Saxegothaea conspicua and Dasyphyllum diacanthoides, and Nothofagus dombeyi in NF). The understory species Chusquea culeou was an important competitor in gaps, especially in STF where the bamboo was more effective inhibiting the recruitment of tree seedlings. The successful recruitment of shade-tolerant tree species beneath endogenous tree-fall gaps indicates that these species follow a gap-phase regeneration mode through which -after several growth releases- they can reach the main canopy. These studies could offer valuable insights for the urgently required restoration and management of Andean old-growth forests.
\end{abstract}

Key words: regeneration dynamics, gap-makers, growth releases, gap-phase regeneration mode.

\section{RESUMEN}

Los claros del dosel son importantes en la dinámica regenerativa de bosques adultos de la cordillera andina ( $c a$. $\left.40^{\circ} \mathrm{S}\right)$. Los objetivos del estudio fueron determinar -en dos rodales antiguos de la cordillera andina- los principales atributos de los claros y los patrones de reclutamiento y crecimiento de la regeneración en ellos. En cada claro se midió el área expandida y para el árbol formador del claro se registró su diámetro a la altura del pecho, dirección de caída y origen (desraizado, quebrado por viento o quebradura de rama); en subparcelas se contabilizaron plántulas arbóreas, brinzales y culmos de Chusquea culeou. Al menos dos tarugos de incremento por claro fueron extraídos para determinar patrones de crecimiento de sucesores potenciales. Fue encontrada mayor área de claros en bosques dominados por Nothofagus spp. (NF) respecto de bosques dominados por tolerantes a la sombra (STF) (25,8 vs. $11,9 \%$ ). Los claros fueron en promedio mayores en NF que en STF (547 vs. $440 \mathrm{~m}^{2}$ ) y originados principalmente por árboles quebrados y desraizados de especies dominantes del dosel (Laureliopsis philippiana, Saxegothaea conspicua y Dasyphyllum diacanthoides en ambos bosques, más Nothofagus dombeyi en NF). La bambúcea Chusquea culeou fue competidor importante en claros, especialmente en STF donde fue inhibió más el reclutamiento de plántulas arbóreas. El reclutamiento de especies tolerantes a la sombra en claros indica que estas especies siguen un modo de regeneración en claros a través del cual -y luego de múltiples liberaciones- pueden alcanzar el dosel principal. Estos estudios pueden ofrecer valiosa contribución a la urgente y necesaria restauración y manejo de bosques adultos andinos.

Palabras clave: dinámica regenerativa, árboles formadores de claros, liberaciones de crecimiento, modo de regeneración en fase de claros.

\section{INTRODUCTION}

Physical and biotic disturbances are major influences on the structure and composition of most temperate forests around the world (Pickett and White 1985, Glenn-Lewin et al. 1992). Many tropical and temperate studies indica- te that small-scale disturbances that generate canopy gaps $\left(<2,000 \mathrm{~m}^{2}\right)$ are key to the population dynamics of trees and to the resulting forest structure and composition (Runkle 1982, Veblen 1985a, 1989, Brokaw 1987, Stewart et al. 1991). Moreover, several studies have related forest composition and regeneration patterns to specific gap 
characteristic such as size and frequency as well as type of tree-fall and gap-maker species (Runkle 1982, Veblen 1985a, Brokaw 1987, Stewart et al. 1991).

In the Valdivian Andes (around $40^{\circ} \mathrm{S}$ ) of Chile, midelevation Nothofagus spp. forests are largely shaped and maintained by catastrophic disturbances (Veblen et al. 1996). Large tracts of Andean montane forests ( $c a$. 700$950 \mathrm{~m}$ a.s.1) are rarely found in a compositional equilibrium or climax condition (Veblen et al. 1980, GlennLewin et al. 1992). Andean montane forests are characterized by emergent trees such as Nothofagus dombeyi (Mirb.) Oerst. and Nothofagus nervosa (Poepp. et Endl.) Oerst. in association with several more abundant shade-tolerant canopy trees such as Saxegothaea conspicua Lindl., Laureliopsis philippiana (Looser) Schodde and Dasyphyllum diacanthoides (Less.) Cabrera (Donoso and Lusk 2007). In canopy gaps, the bamboo Chusquea culeou E. Desv., considered a key species for its important influence on tree regeneration, forms thickets with culms at least six $\mathrm{m}$ tall (Veblen et al. 1980, 1981). In these mixed forests, the lack of saplings and small-diameter individuals of Nothofagus indicates that these shade-intolerant species can not establish in undisturbed old-growth stands (Veblen et al. 1980, Veblen 1985a). Both Nothofagus species are considered opportunist since they establish in large numbers and grow rapidly in open environments (catastrophic mode of regeneration, sensu Veblen 1992) created by large-scale natural disturbances such as landslides and volcanic ash falls, and also by fire and stand-devastating windthrow events (Veblen et al. 1996). In contrast, the two main shade-tolerant trees, L. philippiana and S. conspicua, show some life history traits (e.g., shade tolerance, vegetative reproduction) that allow them to persist and take dominance in the absence of massive disturbances (continuous and gapphase regeneration mode, sensu Veblen 1992, Veblen et al. 1980, 1981, Veblen 1985a). Eventually, in these forests, the replacement of Nothofagus spp. by shade-tolerant species would be prevented due to the longevity of the former $(>500 \mathrm{yr}$ ) and the relatively frequent catastrophic disturbances affecting these montane forests (Veblen et al. 1996).

Although widespread exogenous disturbances importantly determine the overall, long-term forest structure and composition at this elevation, small to medium scale endogenous disturbances -which are subordinate to the larger scale disturbance processes-, especially tree-fall gaps $\left(<2,000 \mathrm{~m}^{2}\right)$ also play an important role (Veblen 1985a). Tree-fall gaps could be defined as those fine-scale disturbances that usually range in size from $<100$ to $2,000 \mathrm{~m}^{2}$ (Runkle 1985), and significantly contribute to the mosaic structure of the forest landscape. Some important features of gaps include: (a) the nature of the gap or canopy opening, (b) gap-makers, (c) size, shape and aspect of gaps, (d) environmental heterogeneity within gaps (e.g., microtopography and microclimate) and (e) interference from understory plants surviving the tree-fall or rapidly occupying the gap (Runkle 1985, Veblen 1992). As a conse- quence, the characteristics of gaps have important effects on tree species recruitment in a forest.

In old-growth stands of Andean montane forests, treefall gaps result in differential opportunities for tree species recruitment. Typically, Nothofagus species have limited opportunities to recruit even in large canopy gaps (i.e., $>1,000 \mathrm{~m}^{2}$ ) due to the release of advance regeneration of the shade-tolerant trees and the vigorous proliferation of the Chusquea spp. bamboos (Veblen et al. 1981, 1985a, 1989). Establishment of Nothofagus species in gaps occurs occasionally on elevated surfaces such as treefall mounds and large logs where competition with other species is reduced (Veblen et al. 1981, 1985a, 1989). In this regard, forest structure and composition may influence the recruitment opportunities of Nothofagus and other late successional species (Veblen 1989, Veblen et al. 1996). Tree-fall gaps are larger and logs more abundant in oldgrowth Nothofagus spp.-dominated stands (Schlegel and Donoso 2008), and these conditions can be advantageous for Nothofagus spp. tree recruitment. Nothofagus dombeyi and $N$. nervosa can reach easily more than $2 \mathrm{~m}$ in diameter at breast height (dbh) and above $50 \mathrm{~m}$ in height, where both species may grow 10 to $30 \mathrm{~m}$ above the main canopy (Donoso and Lusk 2007). Tree-falls of this size trees can create gaps commonly larger than $1000 \mathrm{~m}^{2}$, due in part to the fall of two or three other main canopy trees knocked in the event (Veblen 1985a). Old-growth stands dominated mostly by shade-tolerant tree species have a more compact main canopy of lower height $(<35 \mathrm{~m})$ and dbh than that found in Nothofagus spp.-dominated forests, and therefore, gaps are expected to be of inferior size, mostly favoring the regeneration of shade-tolerant species.

Canopy gaps formation has been largely recognized as an important process among different forest ecosystems. However, there is still a remarkable lack of studies for temperate forests of the southern hemisphere compared to the tropical forests and northern hemisphere temperate forests. To understand the role of tree-fall gaps in the forest dynamics, we examined several features of gaps and tree establishment patterns for two mid-elevation Andean old-growth forests. In this study our purpose is to examine the principal parameters of tree-fall gaps, and the regeneration responses of tree species in two old-growth forests: (a) Nothofagus spp.-dominated forests and (b) shade-tolerantdominated forests. Thus, our specific objectives are to: (1) determine the types and size range of tree-fall gaps and the attributes of gap-makers; and (2) assess tree recruitment and growth patterns in tree-fall gaps of two old-growth forests.

\section{METHODS}

Study area. The study area is located in the Chilean Andes between 750 and $800 \mathrm{~m}$ a.s.l. at the San Pablo de Tregua Experimental Forest $\left(39^{\circ} 38 \mathrm{~S}, 72^{\circ} 05^{\prime} \mathrm{W}\right)$ of Universidad Austral de Chile (figure 1). In this region, old-growth forests (> 300 year old) are dominated by the Coihue-Raulí- 


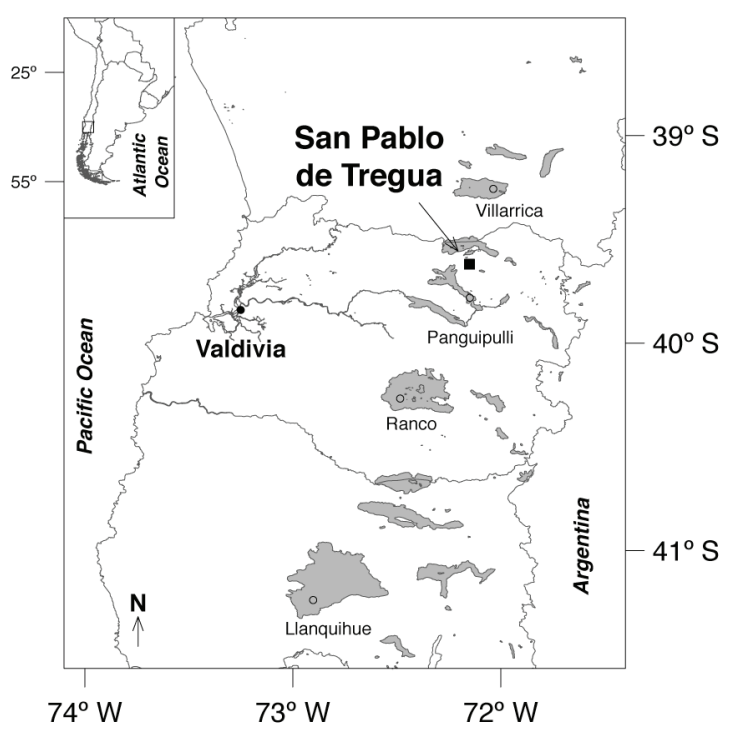

Figure 1. Geographic location of the study area in the Andes range, Chile. The square indicates the location of San Pablo de Tregua Experimental Forest.

Localización geográfica del área de estudio en los Andes, Chile. El cuadrado indica la ubicación del Bosque Experimental de San Pablo de Tregua.

Tepa forest type (Donoso 1993), which is widespread between 600 and 1,000 $\mathrm{m}$ a.s.l. in the Andes of south-central Chile between $37-41^{\circ} \mathrm{S}$, where either coihue ( $N$. dombeyi), raulí ( $N$. nervosa) or both, occupy emergent tiers, and the conifer mañío (S. conspicua), the hardwoods tepa (L. philippiana) and trevo (Dasyphyllum_diacanthoides) occupy the main canopy tier (Veblen et al. 1980, 1981).

We studied two old-growth stands of the coihue-raulitepa forest type without evidence of past human disturbances. One stand is dominated by the emergent $N$. dombeyi; L. philippiana and S. conspicua are the two main canopy species (Nothofagus spp.-dominated forest; NF). This stand is representative of the most common species composition in old-growth forest of this forest type in the Andes of Chile (Veblen et al. 1980, 1981, Donoso 1993). The other stand is dominated by three canopy species, L. philippiana, $S$. conspicua and $D$. diacanthoides. It lacks the emergent Nothofagus species, and has a high density of the Myrte Myrceugenia planipes (Hook. et Arn.) O. Berg trees in the understory $(<12 \mathrm{~m}$ in height) (shade-tolerantdominated forest; STF). Soils are deep and well-drained and are derived from Pleistocene and recent volcanic ash layers in a mountainous area of the Andes range (Veblen 1985b). The steep slopes are generally mantled with a pale orange to reddish-brown porous volcanic ash described as pumiceous lapilli (Wright and Mella 1963). This layer and finer volcanic ash are the parental material of soil in most of the Andean south-central Chile. A west-coast maritime climate with a mild Mediterranean influence characterizes the area. Annual precipitation (mainly rainfall) normally exceeds $3,000 \mathrm{~mm}$ and at higher altitudes it reaches over 5,000 (Oyarzún et al. 2010). The period of least precipitation is summer (January-March); mean monthly precipitation ranges from 100 to over $200 \mathrm{~mm}$.

Forest sampling. In both stands -with an estimated area of 62 ha and 18 ha for NF and STF, respectively- we set up 0.05 ha circular plots, regularly spaced every $40 \mathrm{~m}$ along linear transects, unless the point hit a gap, in which case the plot was located in the next $40 \mathrm{~m}$. Each transect started at a random point, being 80 to $1,000 \mathrm{~m}$ long and separated at least $40 \mathrm{~m}$ from the neighboring transect. The total distance sampled in transects was $2,920 \mathrm{~m}$ in the NF and $4,000 \mathrm{~m}$ in the STF. We set up 80 plots in the NF stand, and 100 plots in the STF stand. The NF stand is located in a terrain with a mean slope of $11 \%$ and a predominant north aspect; the STF stand has a predominant south aspect with a mean slope of $16 \%$. In each plot, we measured all living trees $\geq 5 \mathrm{~cm}$ diameter at breast height $(\mathrm{dbh}=1.3 \mathrm{~m})$ or above buttresses in the case of $N$. dombeyi. We estimated tree density and basal area for each plot and stand. From that data we were able to describe the tree composition and diameter structure of each stand.

Tree-fall gaps. Each stand transect used for circular plots was also used to sample tree-fall gaps. For all gaps $\left(>25 \mathrm{~m}^{2}\right)$ intercepted we measured the length of the opening over the transect direction. The canopy gap was delimited projecting the opening in the canopy to the ground surface. The fraction of the transect length intercepting canopy gaps was taken as an estimate of the percentage of the stand under gap phase (Runkle 1982). For the purpose of this study, gaps were considered as opening $>25 \mathrm{~m}^{2}$ (Veblen 1985a).

To analyze and compare gap features (i.e., area, gapmakers), canopy gaps and expanded gaps (sensu Runkle 1982) were measured in 24 and 22 tree-fall gaps randomly selected from the intercepted gaps for NF and STF, respectively. The area of expanded gaps was defined by the trunk of the trees above $25 \mathrm{~cm}$ dbh bordering the gap, taking into account that trees below that diameter size can commonly be trees established or released because of the gap. The expanded area of each gap (Runkle 1982) was determined by the sum of individual areas based on the distance and angles measured from the centre of the gap to the boles of the border trees using a Vertex III Laser instrument for distances and height measurements. The use of expanded gaps was advantageous because of the superior accuracy with which they can be measured (Veblen 1985a). For each sampled gap, the gap-maker species (trees $>25 \mathrm{~cm}$ dbh that had died and caused the canopy opening) was recorded along with its dbh, fall direction and type of treefall (uprooted, wind-snapped, or crown breakage). In the case of multiple tree-falls, the gap-maker was identified as the tree that had knocked over the other trees.

Each canopy gap was divided into four pie-shaped quadrants of approximately equal size. In each quadrant, four 
to six $1-\mathrm{m}^{2}$ square plots were randomly set for counting tree seedlings (0.05- $2 \mathrm{~m}$ tall) and bamboo culms. Seedling density and cover of bamboo was determined by the average of $1 \mathrm{~m}^{2}$ plots in each quadrant of gaps. Also in each quadrant, saplings (trees $>2 \mathrm{~m}$ tall but $\mathrm{dbh}<5 \mathrm{~cm}$ ) were counted and the dbh of each small tree $(\mathrm{dbh} \geq 5 \mathrm{~cm})$ was measured. To determine which species was most likely to capture a gap, the species and dbh of each potential successor (saplings and trees: $\mathrm{dbh}>5 \mathrm{~cm}$ but $<15 \mathrm{~cm}$ ) were recorded in each quadrant. At least two increment cores per gap were obtained from potential successors and other larger trees (between 15 and $35 \mathrm{dbh}$, when available) to examine their growth patterns. All cores were examined for periods of release using the computer subroutine JOLTS version 6.01 (Holmes 1992). A sustained mayor release was defined as a $100 \%$ average growth increase lasting at least 10 years when compared with the 10 precedent years. In the same $1-\mathrm{m}^{2}$ square plots, we recorded species presence and estimated abundance-dominance values for all vascular plants using Braun-Blanquet cover class values. Cover classes used were: $+=<1 \% ; 1=1-5 \% ; 2=5-25 \% ; 3=25-50 \%$; $4=50-75 \%$; and $5=75-100 \%$. For subsequent data analyses, the mid-point values used for each class were $0.5 \%$, $2.5 \%, 15 \%, 37.5 \%, 62.5 \%$, and $87.5 \%$, respectively.

Statistical analyses included the Student's t-test to compare two independent groups, for the variables gaps size, bamboo density and density of tree seedlings. Data met the assumptions of normality and homocedasticity of variance (Levene test).

In order to assess the gap-makers felling directions, we performed the Rayleigh test of uniformity using the function $<$ r.test $>$ from the R package $\{$ CircStats $\}$ (Jammalamadaka and Sengupta 2001). This test evaluates the significance of the mean direction of the felling trees, testing whether or not the gap-makers fall in the same direction. For all tests we used a $P$-value of 0.05 to consider statistically significant differences between sampled variables.

\section{RESULTS}

Forest structure and composition. The NF stand showed a typical diameter-size class distribution representing an uneven-aged tree population of the shade-tolerant species Saxegothaea conspicua, Laureliopsis philippiana and Dasyphyllum diacanthoides. Moreover, N. dombeyi presented a normal-type diameter-size distribution of few very large individuals indicative of cohorts established after a stand-replacing disturbance (figure 2A). This stand had on average 502 trees per hectare (Standard Deviation (SD) of \pm 21.6 ) and $126 \mathrm{~m}^{2}$ in basal area per hectare $(\mathrm{SD} \pm 6.0)$, of which $41 \mathrm{~m}^{2}$ corresponded to $N$. dombeyi. The STF stand presented a diameter distribution similar to that of the shade-tolerant species, although with higher number of individual of $L$. philippiana and $D$. diacanthoides and the presence of Myrceugenia planipes $(\mathrm{dbh}<60 \mathrm{~cm}$ ) under the main canopy. Emergent $N$. dombeyi trees were mostly absent of the main canopy in STF (figure 2B). This stand had on average $652 \pm 27.8$ trees and $109 \mathrm{~m}^{2} \pm 3.8$ in basal areas per hectare.

Tree-fall gaps. Along the total distance sampled for each stand we intercepted 40 gaps in the NF and 31 gaps in the STF. The fractions of area in canopy gaps in the NF and the STF were $25.8 \%$ and $12.0 \%$, respectively. In both forests the size of expanded gaps was normally distributed (Figure 3). The size distribution of expanded gaps varied from 182 to $1,250 \mathrm{~m}^{2}$ and 164 to $690 \mathrm{~m}^{2}$ for NF and STF, respectively (table 1 ). NF presented $c a .30 \%$ of gaps larger than $700 \mathrm{~m}^{2}$. In contrast, in STF gap sizes were mostly concentrated between 300 and $600 \mathrm{~m}^{2}$ (figure 3). Average size of expanded gaps in the NF and STF were 547 and $440 \mathrm{~m}^{2}$ respectively, but this difference was not significantly different $(P=0.098)$. Saxegothaea conspicua and $N$. dombeyi, the more frequent gap-maker species, generated $41 \%$ and $42 \%$ of the total area in expanded gaps for STF and NF, respectively (table 1).

Table 1. Treefall gap characteristics for STF and NF in San Pablo Experimental forest.

Características de claros para STF y NF en el Bosque Experimental San Pablo de Tregua.

\begin{tabular}{|c|c|c|c|c|c|c|c|c|c|c|}
\hline \multirow{2}{*}{ Site } & \multirow{2}{*}{ Species } & \multirow{2}{*}{$\begin{array}{c}\begin{array}{c}\mathrm{N}^{\circ} \text { of } \\
\text { Gaps }\end{array} \\
\mathrm{N}\end{array}$} & \multicolumn{3}{|c|}{$\begin{array}{c}\text { Gap type } \\
(\%)\end{array}$} & \multicolumn{2}{|c|}{$\begin{array}{l}\text { Diameter of gap } \\
\text { maker }(\mathrm{cm} \mathrm{dbh})\end{array}$} & \multicolumn{3}{|c|}{$\begin{array}{l}\text { Expanded gap } \\
\text { area }\left(\mathrm{m}^{2}\right)\end{array}$} \\
\hline & & & Uprooting & $\begin{array}{l}\text { Wind- } \\
\text { snap }\end{array}$ & $\begin{array}{c}\text { Branch } \\
\text { breakage }\end{array}$ & mean & range & mean & range & $\%$ \\
\hline \multirow{4}{*}{ NF } & Nothofagus dombeyi & 9 & 11.1 & 77.8 & 11.1 & 174 & $65-300$ & 620 & $276-1,250$ & 42 \\
\hline & Saxegothaea conspicua & 7 & - & 100.0 & - & 125 & $27-194$ & 486 & $182-905$ & 26 \\
\hline & Laureliopsis philippiana & 8 & 25.0 & 50.0 & 25.0 & 87 & $34-120$ & 519 & $216-864$ & 32 \\
\hline & Total & 24 & 20.8 & 66.7 & 12.5 & 131 & $27-300$ & 547 & $182-1,250$ & 100 \\
\hline \multirow{4}{*}{ STF } & Saxegothaea conspicua & 9 & 55.6 & 44.4 & 0.0 & 117 & $68-192$ & 445 & $372-585$ & 41 \\
\hline & Laureliopsis philippiana & 7 & 42.9 & 42.9 & 14.3 & 96 & $50-131$ & 373 & $164-535$ & 27 \\
\hline & Dasyphyllum diacanthoides & 6 & 16.7 & 83.3 & - & 116 & $84-190$ & 512 & $319-690$ & 32 \\
\hline & Total & 22 & 40.9 & 54.5 & 4.5 & 110 & $50-192$ & 440 & $164-690$ & 100 \\
\hline
\end{tabular}




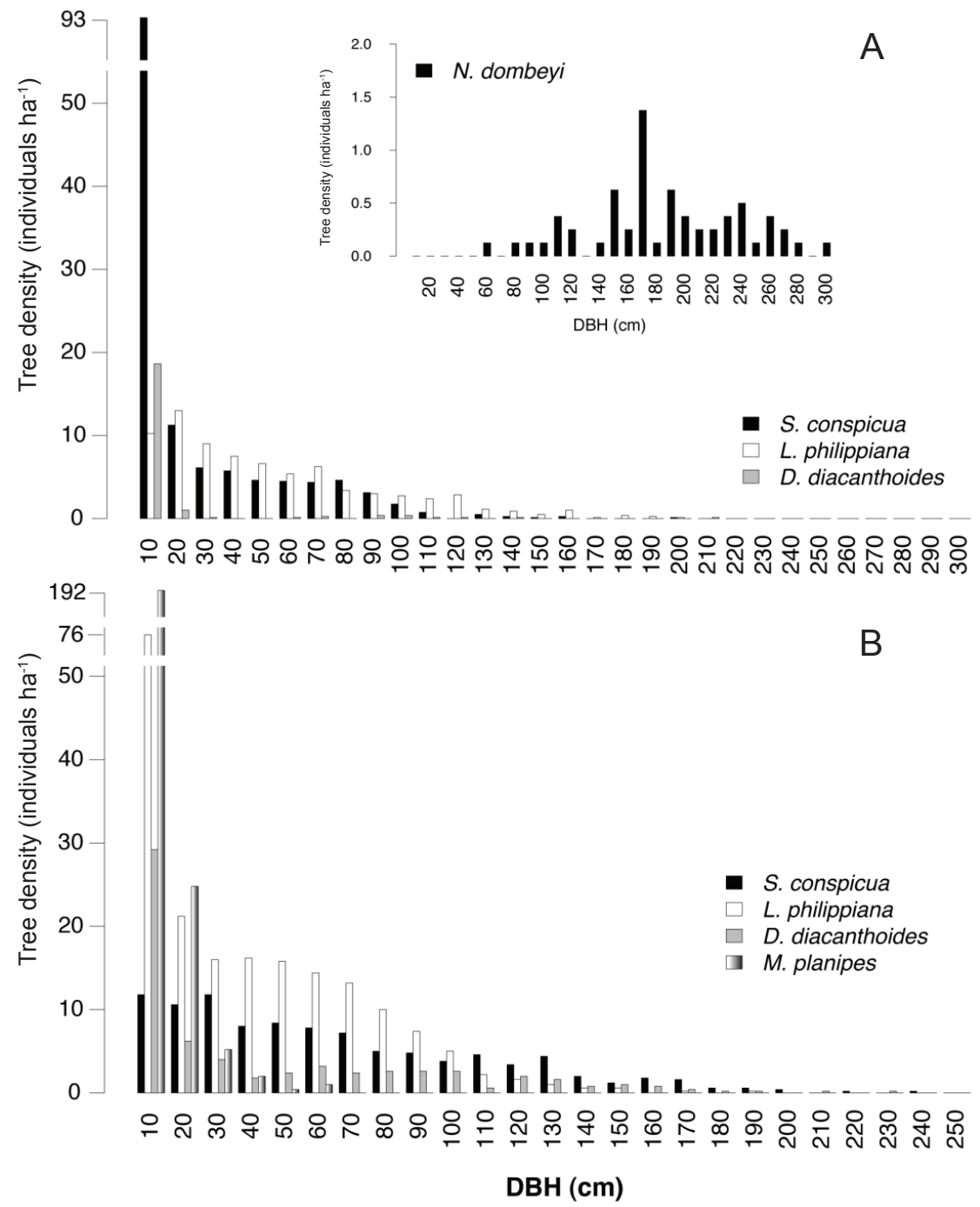

Figure 2. Diameter distribution of A) Nothofagus spp.-dominated stand at San Pablo de Tregua. Main diagram shows the distribution of the three major shade-tolerant species and the inset shows the diameter distribution for $N$. dombeyi; B) shade-tolerant-speciesdominated the stand at San Pablo de Tregua.

Distribución diamétrica de: A) bosques dominados por Nothofagus spp. en San Pablo de Tregua. El diagrama principal muestra la distribución de las tres especies tolerantes a la sombra más comunes y el diagrama secundario muestra la distribución diamétrica de $N$. dombeyi. B) Especies tolerantes a la sombra en el bosque de San Pablo de Tregua.

Most gaps in NF and STF were originated by wind-snap (67\% and $55 \%$ for NF and STF, respectively) and upturned root-plates (21\% and $41 \%$ for NF and STF, respectively) of the emergent $N$. dombeyi, and the dominant canopy species $L$. philippiana, $S$. conspicua, and D. diacanthoides. In addition, fallen branches of large trees of L. philippiana and $N$. dombeyi over $175 \mathrm{~cm}$ in dbh, originated $13 \%$ and $5 \%$ of the gaps in NF and STF, respectively (table 1).

In each stand, all tree species -except $M$. planipes- participated as gap-makers. However, $N$. dombeyi and D. diacanthoides participated exclusively as gap-making species in NF and STF, respectively (table 1). On average, dhb of gap-makers was larger in NF than in STF (table 1; figure 4). Gap-makers of $N$. dombeyi presented a higher proportion of individuals larger than $150 \mathrm{~cm}$ dbh (figure 4). For S. conspicua and $L$. philippiana the dbh of gap-makers was quite similar between sites, but $S$. conspicua showed a higher dbh of gap-makers than that shown by L. philippiana. In STF $84 \%$ (16 cases over 19) of the gap-makers had a treefall direction (South-West or North-West), following closely the bearing of the gap aspect (falling forward; figure 5). Only three gap-makers felled backward. In the case of NF, $71.4 \%$ (15 cases over 21$)$ of the gap-makers had tree-fall directions following the general bearing of the gap aspect. Thus, in NF the felling direction of the gap-makers are randomly distributed $(P>0.05)$ and in STF the gap-makers followed a uniform direction $(P<0.0001$; figure 5 , Rayleigh test of Uniformity). 


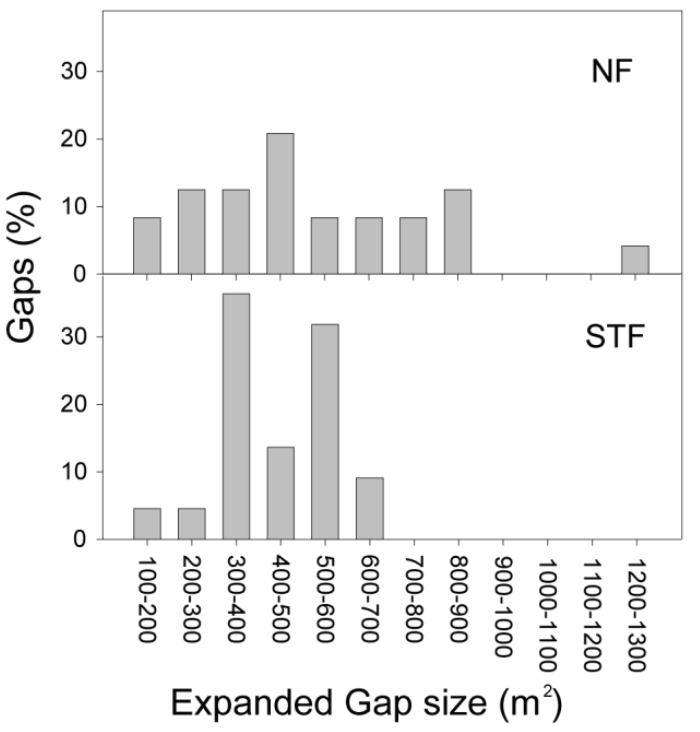

Figure 3. Distribution of size of tree-fall gaps in the NF and STF stands in San Pablo de Tregua.

Distribución de tamaños de claros en los rodales de NF y STF en San Pablo de Tregua.
Responses of understory and tree species to gaps. In NF and STF, main understory species in gaps were represented by Chusquea culeou, Azara lanceolata, Luzuriaga radicans, Hydrangea serratifolia, Blechnum blechnoides and Mitraria coccinea (table 2). Chusquea culeou was the dominant species in gaps with culms $4-5 \mathrm{~cm}$ in diameter and $6 \mathrm{~m}$ in height. Mean density of C. culeou in gaps was not significantly different $(P=0.51)$ between STF and NF (2.53 individuals $\mathrm{m}^{-2}$ and 2.94 individuals $\mathrm{m}^{-2}$, respectively). In NF C. culeou density showed a significant positive relationship with expanded gap size $(\mathrm{r}=0.56$; $P<0.01$ ), but $C$. culeou cover had no significant relationship with tree seedling density $(\mathrm{r}=-0.05 ; P>0.1$, figure 6$)$. In STF, there was no significant pattern between $C$. culeou density and gap size $(\mathrm{r}=-0.35 ; P>0.05)$, though cover of $C$. culeou had a significant negative relationship with tree seedling density in gaps $(\mathrm{r}=-0.21 ; P<0.05$, figure 6$)$.

Tree responses to tree-fall gaps were characterized by the establishment and/or release of advance regeneration of shade-tolerant species. In NF, L. philippiana was the most abundant seedling species in tree-fall gaps (figure 7). In STF, seedlings of $L$. philippiana, M. planipes, and

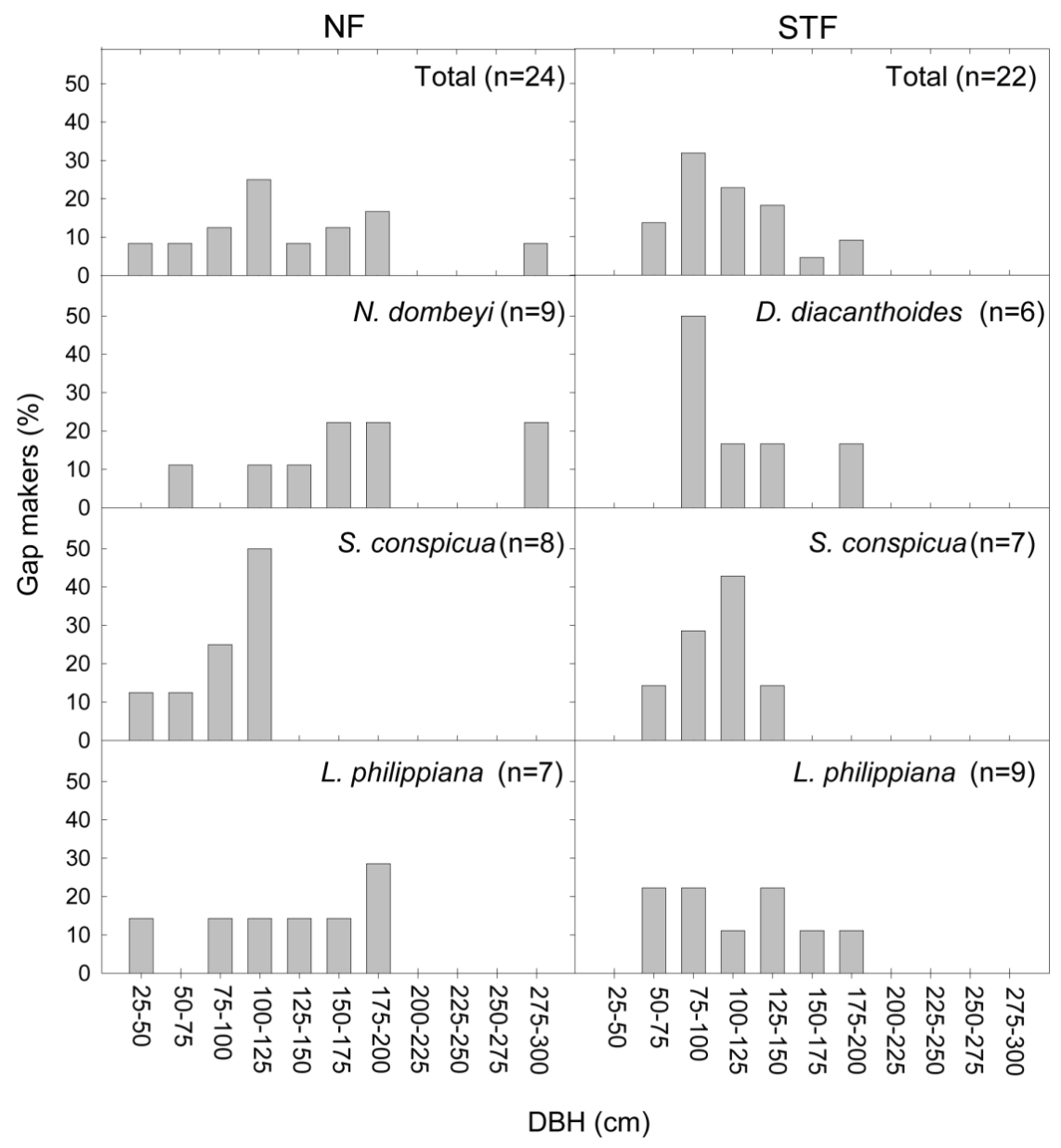

Figure 4. Diameter size distribution of gap-makers in the NF and STF stands in San Pablo de Tregua.

Distribución diamétrica de árboles formadores de claros en los rodales de NF y STF en San Pablo de Tregua. 


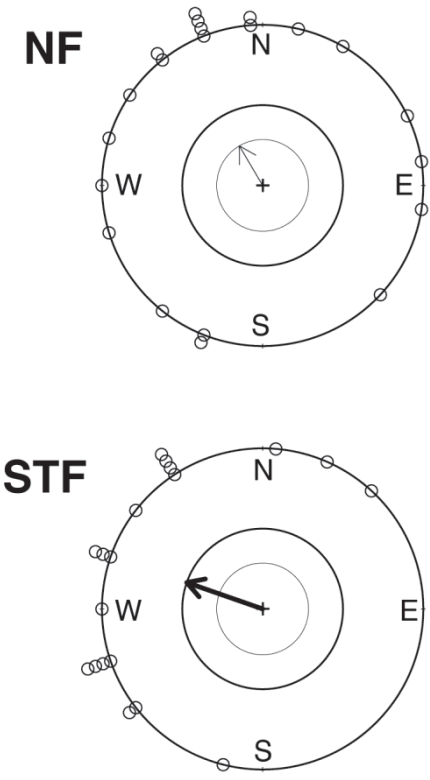

Figure 5. Distribution of gap-makers felling directions (peripheral angular scale) for 19 and 21 gaps in STF and NF, respectively. The inner circle (thinner line) indicates the non-significance probability $(P>0.05)$ and the outer circle (dark line) the significance $(P<0.05)$ of the Rayleigh test.

Distribución de la dirección de caída de árboles formadores de claros (escala angular periférica) para 19 y 21 claros en STF y NF, respectivamente. El circulo interior (línea delgada) indica la probabilidad no significativa $(P>0,05)$ y el circulo exterior (línea oscura) la significancia $(P<0,05)$ de la prueba de Rayleigh.

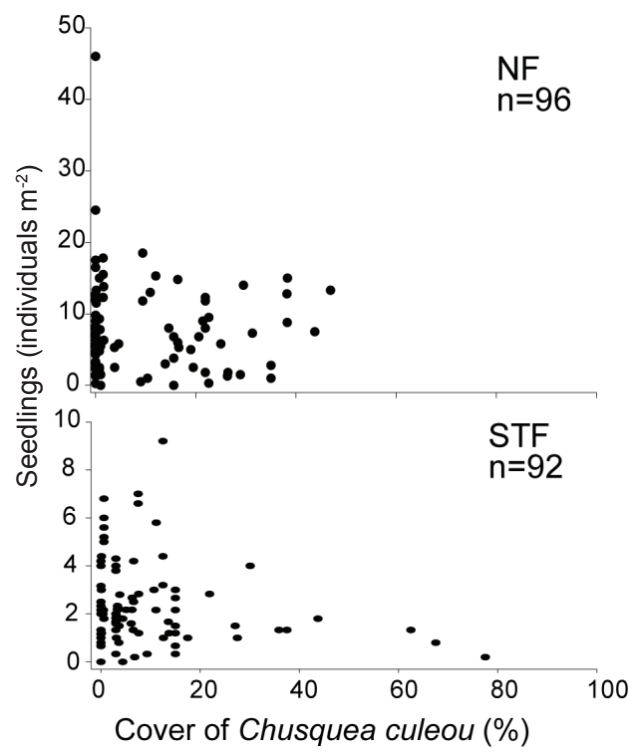

Figure 6. Tree seedlings ( $<2 \mathrm{~m}$ tall) and bamboo cover relationships for STF and NF. Seedling density and cover of bamboo represent the average of five $1 \mathrm{~m}^{2}$ plot in each quadrant of gaps (n $=$ number of quadrant).

Relación entre plántulas arbóreas $(<2 \mathrm{~m}$ alto) y cobertura de bambú para STF y NF. La densidad de plántulas y cobertura de C. culeou representa el promedio de cinco parcelas de $1 \mathrm{~m}^{2}$ en cada cuadrante de los claros ( $\mathrm{n}=$ número de cuadrantes).

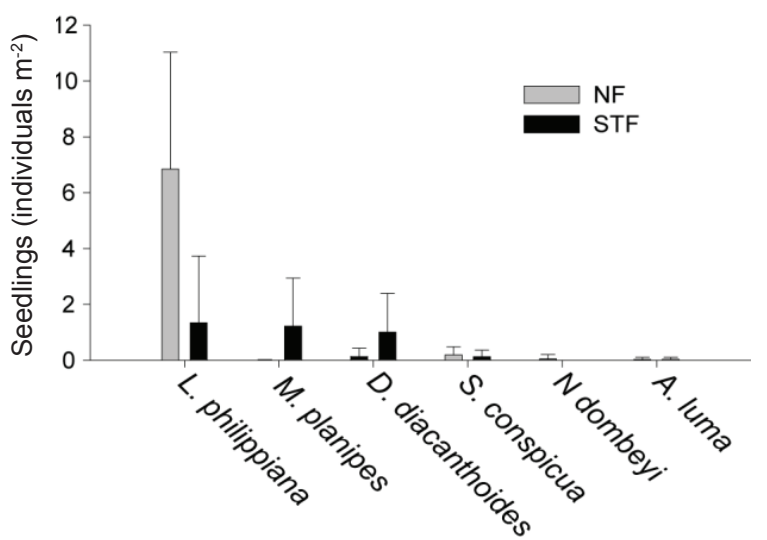

Figure 7. Density of tree seedlings $(<2 \mathrm{~m}$ tall) in gaps for STF and NF.

Densidad de plántulas arbóreas ( $<2$ m altura) en claros en STF y NF.

D. diacanthoides reached comparatively similar densities in tree-fall gaps. In both sites, seedlings of $S$. conspicua had low number of individuals. Nothofagus dombeyi was only present in NF with a very low number of individuals mostly established above logs. Excluding the small tree M. planipes, density of tree seedlings in gaps in NF was significantly higher than in STF (26.4 vs $15.6 ; P=0.04$ ), mostly given by the higher recruitment of $L$. philippiana .

In NF and STF, tree-fall gaps showed relatively high numbers of sapling and trees of shade-tolerant species (potential successors; table 3). In NF and STF L. philippia$n a$ and $D$. diacanthoides were the most abundant species among saplings, especially the former. Moreover, in STF, saplings of $M$. planipes participated with very high numbers in comparison with NF. In both sites, S. conspicua and Myrceugenia chrysocarpa (O. Berg) Kausel, another small tree species, presented very low numbers of individuals. Nothofagus dombeyi was barely represented in gaps. Of the 24 gaps in NF, saplings of this species were found only in two gaps. Overall, potential successors in tree-fall gaps appear to be dominated mainly by L. philippiana, $D$. diacanthoides and S. conspicua. Growth patterns of these shade-tolerant species in tree-fall gaps showed frequent releases over their life span that allowed these individuals to reach the main canopy (figure 8).

\section{DISCUSSION}

Old-growth forests. The old-growth Nothofagus-dominated forests, with merely few emergent individuals of this species above the main canopy, represent a cohort established after a stand-replacing disturbance more than, at least, three hundred year earlier (Veblen et al. 1981, Veblen 1985a). The shade-tolerant species, Saxegothaea conspicua, Laureliopsis philippiana and Dasyphyllum diacanthoides, showed a negative exponential size-distribu- 
Table 2. Importance values for undergrowth species (shrubs, vines, ferns and herbs) in gaps for NF and STF. Fr = frequency; Cob = cover; VI = importance value.

Valores de importancia para especies de sotobosque (arbustos, trepadoras, helechos y hierbas) en claros para NF y STF. Fr = frecuencia; Cob = cobertura; VI = valor de importancia .

\begin{tabular}{|c|c|c|c|c|c|c|c|}
\hline \multirow{2}{*}{ Growth forms } & \multirow{2}{*}{ Family } & \multicolumn{3}{|c|}{$\mathrm{NF}$} & \multicolumn{3}{|c|}{ STF } \\
\hline & & $\mathrm{Fr} \%$ & $\mathrm{Cob} \%$ & VI & $\mathrm{Fr} \%$ & Cob $\%$ & VI \\
\hline \multicolumn{8}{|l|}{ Shrubs } \\
\hline Chusquea culeou E. Desv. & Poaceae & 13,6 & 30,2 & 43,8 & 8,9 & 15,9 & 24,8 \\
\hline Azara lanceolata Hook.f. & Flacourtiaceae & 14,6 & 18,5 & 33,1 & 9,2 & 10,4 & 19,7 \\
\hline Solanum gayanum Dunal & Solanaceae & 0,4 & 0,1 & 0,5 & 0,2 & 0,3 & 0,5 \\
\hline Ribes magellanicum Poir. & Saxifragaceae & 0,5 & 0,1 & 0,6 & 0,1 & 0,1 & 0,2 \\
\hline Baccharis sp. & Asteraceae & 0 & 0 & 0 & 0,7 & 0,7 & 1,5 \\
\hline Greigia sp. & Bromeliaceae & 0,8 & 0,6 & 1,4 & 1,3 & 1,1 & 2,4 \\
\hline \multicolumn{8}{|l|}{ Vines } \\
\hline Hydrangea serratifolia (H. et A.) F. Phil. & Hydrangeaceae & 6,2 & 4,3 & 10,5 & 14,4 & 10,8 & 25,1 \\
\hline Luzuriaga radicans Ruiz et Pavón. & Liliaceae & 18,3 & 5,8 & 24,1 & 12,8 & 4,7 & 17,5 \\
\hline Mitraria coccinea $\mathrm{Cav}$. & Gesneriaceae & 8,8 & 10,3 & 19,1 & 5,3 & 3,2 & 8,5 \\
\hline Asteranthera ovata (Cav.) Hanst. & Gesneriaceae & 7,2 & 8,2 & 15,4 & 0 & 0 & 0 \\
\hline Nertera granadensis (Mutis ex L.f.) Druce & Rubiaceae & 5,3 & 6,0 & 11,3 & 3,5 & 3,2 & 6,7 \\
\hline Campsidium valdivianum (Phil.) Skottsb. & Bignoniaceae & 4,7 & 1,3 & 6,0 & 2,0 & 0,8 & 2,8 \\
\hline Chrysosplenium valdivicum Hook & Saxifragaceae & 1,2 & 0,3 & 1,5 & 2,3 & 1,8 & 4,1 \\
\hline Dioscorea sp. & Dioscoreaceae & 0,1 & 0,0 & 0,1 & 0 & 0 & 0 \\
\hline Sarmienta repens Ruiz et Pavón. & Gesneriaceae & 0,1 & 0,1 & 0,2 & 0,6 & 0,5 & 1,1 \\
\hline Elytropus chilensis (A.DC.) Muell.Arg. & Apocynaceae & 0 & 0 & 0 & 1,6 & 1,2 & 2,8 \\
\hline Griselinia sp. & Cornaceae & 0,7 & 0,7 & 1,4 & 0,1 & 0,1 & 0,2 \\
\hline \multicolumn{8}{|l|}{ Ferns } \\
\hline Blechnum blechnoides Keyserl. & Blechnaceae & 2,7 & 2,7 & 5,4 & 19,0 & 31,0 & 50,0 \\
\hline Ctenitis spectabilis (Kaulf.) Kunkel & Dryopteridaceae & 0,5 & 0,2 & 0,7 & 2,5 & 2,3 & 4,8 \\
\hline Hymenophyllum sp. & Hymenophyllaceae & 0,4 & 0,7 & 1,1 & 0,3 & 0,4 & 0,7 \\
\hline Lophosoria quadripinnata (J.F. Gmel.) C. Chr. & Lophosoriaceae & 0,2 & 0,1 & 0,3 & 1,6 & 2,4 & 4,0 \\
\hline Blechnum chilensis (Kaulf.) Mett. & Blechnaceae & 2,4 & 2,0 & 4,4 & 0,1 & 0,2 & 0,3 \\
\hline Gleichenia sp. & Gleicheniaceae & 0,1 & 0,3 & 0,4 & 0,0 & 0,2 & 0,2 \\
\hline \multicolumn{8}{|l|}{ Herbs } \\
\hline Uncinia sp. & Cyperaceae & 0,7 & 0,6 & 1,4 & 2,0 & 1,7 & 3,7 \\
\hline Dysopsis glechomoides (A. Rich.) Muell.-Arg. & Euphorbiaceae & 5,6 & 3,8 & 9,4 & 7,1 & 5,7 & 12,9 \\
\hline Loasa acanthifolia Desr. & Loasaceae & 4,6 & 2,1 & 6,7 & 4,0 & 1,4 & 5,4 \\
\hline Acaena ovalifolia R. et $\mathrm{P}$. & Rosaceae & 0,1 & 0,0 & 0,1 & 0 & 0 & 0 \\
\hline \multirow[t]{2}{*}{ Urtica sp. } & Urticaceae & 0,1 & 0,1 & 0,2 & 0,1 & 0,0 & 0,1 \\
\hline & Total & 100 & 99 & 199 & 100 & 100 & 200 \\
\hline
\end{tabular}


Table 3. Size-class frequencies of trees $>2 \mathrm{~m}$ tall in 22 and 24 gaps for STF and NF, respectively. Myrceugenia planipes is included for comparison. Potential successors are saplings and trees with $\mathrm{dbh}>5 \mathrm{~cm}$ but $<15 \mathrm{~cm}$. We include occasionally present isolated trees $(\mathrm{dbh}>15 \mathrm{~cm})$ within the gap.

Frecuencia por clases de tamaño de árboles $>2 \mathrm{~m}$ de alto en 22 y 24 claros para STF y NF, respectivamente. Se incluye M. planipes por razones de comparación. Sucesores potenciales corresponden a brinzales y árboles $>5 \mathrm{~cm}$ pero $<15 \mathrm{~cm}$ dap. Se incluye árboles jóvenes y aislados ocasionalmente presentes ( $>15 \mathrm{~cm}$ dap) dentro del claro.

\begin{tabular}{|c|c|c|c|c|c|c|c|c|c|}
\hline \multirow{2}{*}{ Species } & \multicolumn{9}{|c|}{ Size class (cm dbh) } \\
\hline & $<5$ & $5-9$ & $10-14$ & $15-19$ & $20-24$ & $25-29$ & $30-34$ & $>35$ & Total \\
\hline \multicolumn{10}{|l|}{ STF } \\
\hline L. philippiana & 146 & 28 & 21 & 12 & 5 & 3 & 2 & 0 & 217 \\
\hline D. diacanthoides & 188 & 26 & 5 & 6 & 3 & 0 & 2 & 1 & 230 \\
\hline S. conspicua & 1 & 2 & 3 & 1 & 1 & 1 & 1 & 4 & 10 \\
\hline M. planipes & 298 & 55 & 19 & 5 & 1 & 1 & 0 & 1 & 379 \\
\hline M. crysocarpa/luma & 6 & 6 & 0 & 0 & 0 & 0 & 0 & 0 & 12 \\
\hline \multicolumn{10}{|l|}{$\mathrm{NF}$} \\
\hline L. philippiana & 538 & 109 & 54 & 21 & 8 & 5 & 1 & 5 & 736 \\
\hline D. diacanthoides & 72 & 15 & 11 & 4 & 1 & 1 & 0 & 0 & 104 \\
\hline S. conspicua & 13 & 10 & 6 & 8 & 9 & 4 & 7 & 6 & 57 \\
\hline M. planipes & 4 & 3 & 1 & 2 & 0 & 0 & 0 & 0 & 10 \\
\hline M. crysocarpa/luma & 2 & 1 & 0 & 0 & 0 & 0 & 0 & 0 & 3 \\
\hline N. dombeyi & 4 & 0 & 0 & 1 & 0 & 0 & 0 & 0 & 5 \\
\hline
\end{tabular}

tion, indicative of an uneven-aged tree population. For this forest, Donoso and Lusk (2007) reported that the similarity of $N$. dombeyi diameter distributions throughout the stand is consistent with a homogeneous disturbance history over the study area, and that the frequent clustering of $N$. dombeyi in small groups of two to four trees is consistent with establishment after patchy blowdown by windstorms, as previously reported by Veblen (1985a) for forests of this type elsewhere in the region. The STF stands showed a similar diameter-size class distribution to that of the shadetolerant species $S$. conspicua, L. philippiana and D. diacanthoides, representing a more advanced development stage -without major disturbances- of this type of forests.

Origin and characteristics of canopy gaps. The stages of development - and consequently the structure and composition- of the forest mosaic is an important factor in determining differences in main gap features and canopy heterogeneity (Runkle 1982, Brokaw 1987). The fraction of the area in canopy gaps in NF (25.8\%) was relatively higher compared with previous estimates for these midelevation forests (13.3\%; Veblen, 1985a). However, the area in canopy gaps in STF (12\%) was fairly similar to coastal lowland old-growth forests ( $\mathrm{ca} .8 \%$ to $11 \%$; Veblen 1985a, Gutiérrez et al. 2009), though very different from that found by Armesto and Fuentes (1988; $29 \%$ of canopy gaps) for similar coastal forests. All species (the emergent $N$. dombeyi, and dominant canopy species L. philippiana, S. conspicua, and D. diacanthoides) participated with similar proportions as gap-makers; however, $N$. dombeyi and S. conspicua accounted for the high total area in expanded gaps (42\% and $41 \%$ ) in each forest. As in other temperate forests in the southern hemisphere (Veblen 1985a, Steward et al. 1991, Rebertus and Veblen 1993, Gutiérrez et al. 2009), most gaps in NF and STF were originated by wind-snaps followed by upturned root-plates.

Similarly, gap size was importantly determined by forest structure and composition. Mainly associated with the dominance of large $N$. dombeyi, ca. $30 \%$ of gaps in NF reached over $700 \mathrm{~m}^{2}$ compared to STF where gap sizes were mostly concentrated below $600 \mathrm{~m}^{2}$, i.e. larger gaps in NF $\left(>1,000 \mathrm{~m}^{2}\right)$ commonly resulted from multiple tree-falls after large trees (especially emergent $N$. dombeyi trees with $\mathrm{dbh}>200 \mathrm{~cm}$ ) knock down their neighbors; a finding that is consistent with previous reports by Veblen et al. (1996). In most cases, such openings are caused by infrequent, but severe, wind storms ${ }^{1}$ (Veblen 1985a). Overall, these canopy gap parameters adjusted very closely to the previously determined gap features (e.g., size, origin) for this montane old-growth forest (Veblen 1985a); however, canopy gap

Personal observation of ME González. 


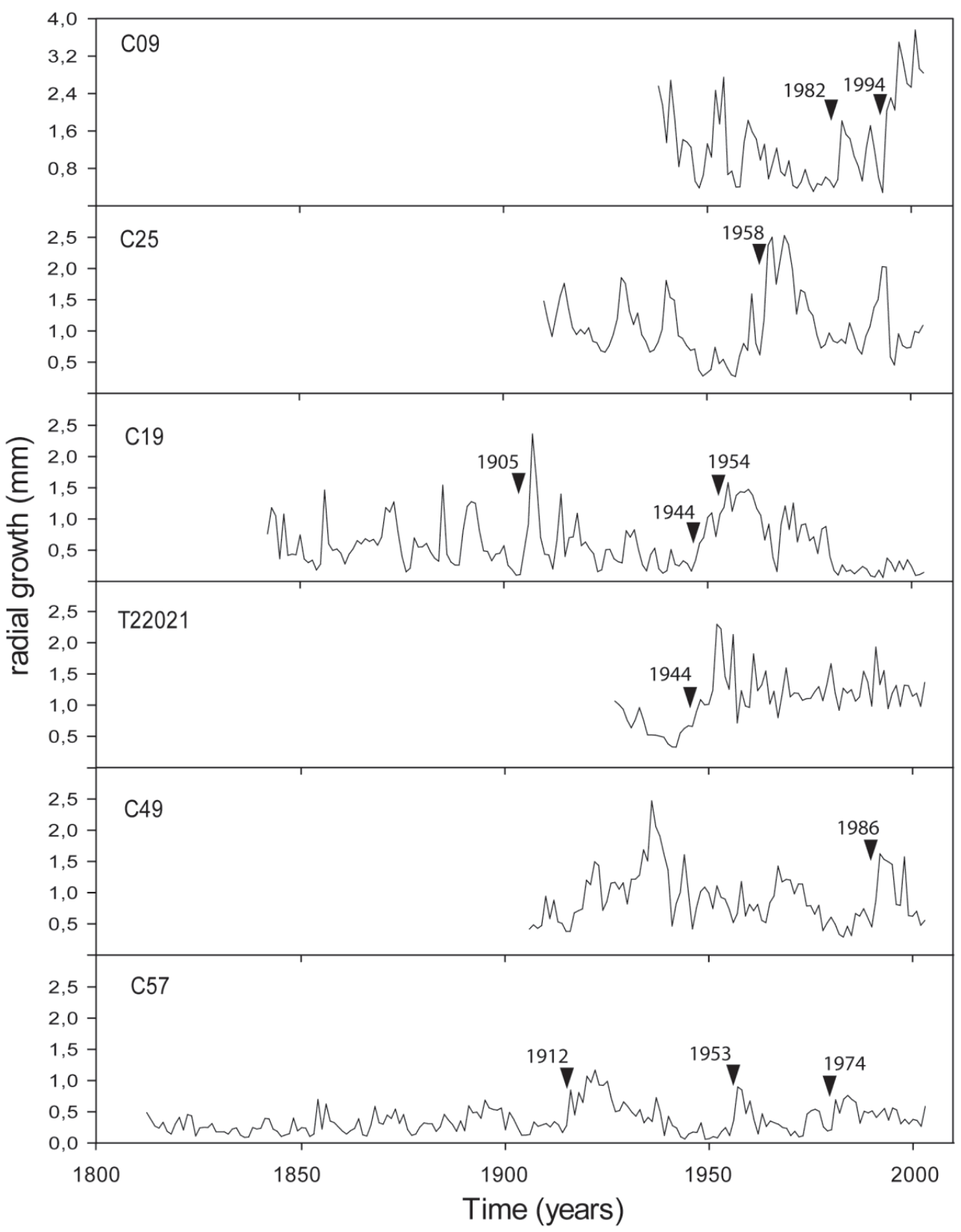

Figure 8. Yearly radial increments for a subsample of potential successors located in gaps showing sustained increases in growth rates. Arrowheads identify the starting years of periods that qualify as releases by the criteria outlined in the text. Laureliopsis philippiana (C9, C49, T22021) and S. conspicua (C19, C25, C57).

Incrementos radiales anuales para una submuestra de sucesores potenciales ubicados en claros que muestran incrementos sostenidos en sus tasas de crecimiento. Las flechas identifican periodos que califican como liberaciones de acuerdo al criterio descrito en el texto. L. philippiana (C9, C49, T22021) y S. conspicua (C19, C25, C57).

area was larger $\left(>500 \mathrm{~m}^{2}\right)$ than that reported for old-growth coastal temperate rainforests $\left(<300 \mathrm{~m}^{2}\right.$; Veblen 1985a, Armesto and Fuentes 1988, Gutiérrez et al. 2009).

Tree-fall gaps and tree regeneration dynamics. In both forest stands, tree-fall gaps were commonly dominated by the advance regeneration of the shade-tolerant and slowgrowing species L. philippiana, D. diacanthoides, S. cons- picua, and the small canopy tree $M$. planipes. Moreover, L. philippiana, usually established mostly from root suckers, was the most abundant tree species regenerating in tree-fall gaps, especially in NF (Veblen et al. 1981, Veblen 1985a). Comparatively, $S$. conspicua and $D$. diacanthoides had low numbers of seedlings under gaps, which is consistent with findings by Veblen et al. (1980). Apparently, seedling establishment would be favored in years of high 
seed production of these mast seeding species (Donoso 1993). Although all three species, L. philippiana, S. conspicua and $D$. diacanthoides, may recruit and survive under a relatively close and heterogeneous forest canopy in oldgrowth forest (Veblen et al. 1980, 1981), their successful recruitment and growth beneath endogenous tree-fall gaps (ca. 25-1,000 $\mathrm{m}^{2}$ ) demonstrate that they also favorably follow a gap-phase regeneration mode (sensu Veblen 1992) through which -after several decades- they can reach the main canopy (Veblen et al. 1981, Veblen 1985a, González et al. 2002, Gutiérrez et al. 2009). In fact, in coastal temperate rain forests, $L$. philippiana and $S$. conspicua have shown a strong preference for fallen logs as regeneration microsites, where they find better access to light (Lusk 1995, Christie and Armesto 2003). Similarly, uprooted trees that expose mineral soil and form mounds favor the recruitment of these species (Veblen et al. 1980). In contrast, seedlings of the opportunistic and very light-demanding species $N$. dombeyi establish in NF with a very low number of individuals, mostly above logs (Veblen 1985a, 1989). The lack of regeneration of $N$. dombeyi in this study illustrates that, as previously demonstrated, periodic large-scale exogenous disturbances such as fire, landslides, volcanic ash falls and blowdowns are the main processes promoting regeneration opportunities for the maintenance of this and other Nothofagus species (e.g., N. dombeyi, N. nervosa, N. obliqua, N. pumilio; Veblen et al. 1996).

We found that, in general, a higher seedling density of the different tree species was associated with lower bamboo cover in gaps. However, more abundant and diverse microsite conditions, such as those found in NF gaps (i.e., larger logs, multiple tree falls, more open canopy) seemed to favor a higher density of seedlings in gaps of this forest. Saxegothaea conspicua seemed to be more sensitive to the inhibitory influence of $C$. culeou than L. philippiana in gaps, which is consistent with its apparent more mid shade-tolerant character compared with the latter (Donoso and Lusk 2007). The persistence of S. conspicua in these forests is in general largely explained by its capacity to develop adventitious roots from old rotten trees (dbh $>60 \mathrm{~cm}$ ) (Veblen et al. 1980). The understory species C. culeou is an important competitor in tree-fall gaps. It has been proved that large-scale disturbances are required for the regeneration of $N$. dombeyi in these forests because of the heavy competition of understory species such as C. culeou and shade-tolerant tree species (Veblen et al. 1980, 1981). Otherwise, in regions without or with poor understories of shade-tolerant trees species and Chusquea species, $N$. dombeyi is able to regenerate even in relatively small canopy gaps (Veblen 1989, Veblen et al. 1996). In regions such as the one of the present study, gaps -especially larger ones- favor a more important proliferation and vigor of C. culeou compared with its development under continuous tree canopy, which can inhibit the recruitment of tree seedlings (Veblen 1985a, Veblen 1989). In other southern hemisphere Nothofagus spp. forests similar in- hibitory effect from dense fern cover restricts seedlings of N. fusca and N. mienziessi to elevated substrates (e.g., logs; Steward et al. 1991).

One strategy of tree to escape understory competition and reach the canopy seems to be through episodic growth releases. In the present study, main potential successors, such as $L$. philippiana, $D$. diacanthoides and $S$. conspicua growing in tree-fall gaps, showed evidence of frequent radial growth releases during their first decades of establishment. Sometimes these juvenile trees experienced more than one release, suggesting that gaps could have been enlarged -by secondary expansion events- decades after the initiating event, resulting in multiples opportunities of growth releases to access the canopy (Veblen 1985a, Veblen et al. 1996). These frequent radial releases of potential successors -after years or decades of suppressionand the tree recruitment patterns observed suggest that frequent gap-phase disturbance regimes play an important role for the regeneration dynamics of shade-tolerant species and the overall development of these forests.

Management implication. Despite the striking influence of large-scale disturbances in these Andean forests, the differential characteristics of tree-fall gaps importantly determines the regeneration patterns of the component species in these forests, i.e. gap heterogeneity might result in distinct regeneration opportunities according to microsite preferences for seedling establishment. These studies will yield valuable insights for the required restoration and management of Andean old-growth forests largely burned, logged and high-graded during the last 120 years. Future restoration and management of these highly diverse and productive forests must consider the life-history strategy and regeneration modes of each of the species for enhancing and maintaining their integrity and resilience. Considering the silvics of the main species in these forests, and based on this and past studies, it becomes evident that silviculture of these forests needs to consider the creation of sufficiently large gaps and competition control if it is aimed at maintaining a given proportion of Nothofagus spp. in the system. Otherwise, some sort of traditional unevenaged silviculture (e.g. selection cuts) should be suitable for the management of forests dominated by more shade-tolerant species, although competition control may continue to be necessary since C. culeou is present not only in gaps but even under the canopy of these forests. Studies of forest dynamics are becoming increasingly relevant to inform present and future management of these forests.

\section{ACKNOWLEDGEMENTS}

This work was supported by the International Foundation for Science (Sweden) [grant D-3497-1 to P. J. D.]. The principal author also thanks the Center for Climate and Resilience Research (CR) ${ }^{2}$ (Programa CONICYT/ FONDAP/15110009). 


\section{REFERENCES}

Armesto JJ, ER Fuentes. 1988. Tree species regeneration in a mid-elevation, temperate rain forest in Isla de Chiloe, Chile. Vegetatio 74: 151-159.

Brokaw NVL. 1987. Gap-phase regeneration of three pioneer tree species in a tropical forest. Journal of Ecology 75: 9-19.

Christie DA, JJ Armesto. 2003. Regeneration microsites and tree species coexistence in temperate rain forests of Chiloé Island, Chile. Journal of Ecology 91: 776-784.

Donoso C. 1993. Bosques templados de Chile y Argentina. Variación, Estructura y Dinámica. Santiago, Chile. Editorial Universitaria. $484 \mathrm{p}$.

Donoso C, D Alarcón, P Donoso, B Escobar, A Zuñiga. 2013. Laureliopsis philippiana. In Donoso $\mathrm{C}$ eds. Las Especies Arbóreas de los Bosques Templados de Chile y Argentina. Autoecología. Valdivia, Chile. Marisa Cuneo Ediciones. p. 303-314.

Donoso PJ, C Lusk. 2007. Differential effects of emergent Nothofagus dombeyi on growth and basal area of canopy species in an old-growth temperate rainforest. Journal of Vegetation Science 18: 675-684.

Glenn-Lewin DC, RK Peet, TT Veblen. 1992. Plant Succession - Theory and Prediction. London, UK. Chapman and Hall. $352 \mathrm{p}$.

González ME, TT Veblen, C Donoso, L Valeria. 2002. Tree regeneration responses in a lowland Nothofagus-dominated forest after bamboo dieback in South-Central Chile. Plant Ecology 161: 59-73.

Gutiérrez AG, JJ Armesto, JC Aravena, M Carmona, NV Carrasco, DA Christie, MP Pena, C Perez, A Huth. 2009. Structural and environmental characterization of old-growth temperate rainforests of northern Chiloe Island, Chile: Regional and global relevance. Forest Ecology and Management 258: 376-388.

Jammalamadaka SR, A Sengupta. 2001. Topics in circular statistics. Series in Multivariate analysis. London, UK. World Scientific Publishing. 321 p.

Lusk CH. 1995. Seed size, establishment sites and species coexistence in a Chilean rainforest. Journal of Vegetation Science 6 (2): 249-256.

Oyarzún CE, R Godoy, J Staelens, PJ Donoso, NE Verhoest. 2011. Seasonal and annual throughfall and stemflow in Andean temperate rainforests. Hydrological Processes 25: 623-633.

Pickett STA, PS White (eds). 1985. The Ecology of Natural Dis- turbance and Patch Dynamics. New York, USA. Academic Press. $472 \mathrm{p}$.

Rebertus AJ, TT Veblen. 1993. Structure and tree-fall gap dynamics of old-growth Nothofagus forests in Tierra del Fuego, Argentina. Journal of Vegetation Science 4: 641-654.

Runkle JR. 1982. Patterns of disturbance in some old-growth mesic forests of eastern North America. Ecology 63: 15331546.

Runkle JR. 1985. Disturbance regimes in temperate forest. In: Pickett STA, PS White eds. The ecology of natural disturbance and patch dynamics. San Diego, USA. Academic Press. p. 17-33.

Schlegel BC, PJ Donoso. 2008. Effects of forest type and stand structure on coarse woody debris in old-growth rainforests in the Valdivian Andes, south-central Chile. Forest Ecology and Management 255: 1906-1914.

Stewart GH, AB Rose, TT Veblen. 1991. Forest development in canopy gaps in old-growth beech (Nothofagus) forests, New Zealand. Journal of Vegetation Science 2: 679-690.

Veblen TT. 1985a. Forest development in tree-fall gaps in the temperate rain forest of Chile. National Geographic Research 1: 162-183.

Veblen TT. 1985b. Stand dynamics in Chilean Nothofagus forests. In Pickett STA, PS White eds. The ecology of natural disturbance and patch dynamics. San Diego, USA. Academic Press. p. 35-51.

Veblen TT. 1989. Tree regeneration responses to gaps along a transandean gradient. Ecology 70: 541-543.

Veblen TT. 1992. Regeneration dynamics. In Glenn-Lewin DC, RK Peet, TT Veblen eds. Plant succession: theory and prediction. London, UK. Chapman and Hall. p. 152-187.

Veblen TT, C Donoso, T Kitzberger, AJ Rebertus. 1996. Ecology of southern Chilean and Argentinean Nothofagus forests. In Veblen TT, RS Hill, J Read eds. The Ecology and Biogeography of Nothofagus Forests. New Haven, USA. Yale University Press. p. 293-353.

Veblen TT, C Donoso, FM Schlegel, B Escobar. 1981. Forest dynamics in south-central Chile. Journal of Biogeography 8: 211-247.

Veblen TT, FM Schlegel, B Escobar. 1980. Structure and dynamics of old-growth Nothofagus forests in the Valdivian Andes, Chile. Journal of Ecology 68: 1-31.

Wright C, A Mella. 1963. Modifications to the soil pattern of south-central Chile resulting from seismic and associated phenomena during the period May to August 1960. Bulletin of Seismological Society of America 53: 1367-1402. 